\title{
Cultural competence and relational closeness: examining refugee education
}

\author{
R.D. Nordgren \\ National University, San Diego, California, USA
}

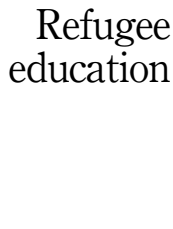

\begin{abstract}
Purpose - The purpose of this paper is to provide a historical and current accounting of the state of refugee education in both the USA and Sweden. The growing diaspora of people around the globe implores educators to utilize effective models and strategies to meet the needs of refugees, as well as to advocate policies that aid in this utilization. Sweden has the highest rate of refugee acceptance in Europe, and the USA has the greatest number of immigrants in the west.

Design/methodology/approach - A review of the literature formatted to provide the reader with a historical accounting of the states of refugee education in both host nations, as well as the current states. Strategies and promising policies are introduced based on the literature and the author's own research conducted in Sweden.

Findings - The paper addresses the history and present situations of two host nations, Sweden and the USA, who have differing education systems and histories of immigration. Concerns and two possible solutions offered were to increase opportunities for interaction between native and refugee populations; and bolster funding for the education of refugee school-age children and adolescents, and adults so that effective strategies and environment described in the literature can be put into place by effectively trained educators. These solutions could improve the cultural competence among all peoples in both nations, better enabling the two countries to provide economically and socially sustainable environments for all of their inhabitants.

Research limitations/implications - The examination of these two nations' education of refugees may shed light on the worldwide challenges of refugees and mass immigration.

Practical implications - The solutions offered in the paper could improve the cultural competence among all peoples in both nations, better enabling the two countries to provide economically and socially sustainable environments for all of their inhabitants.

Originality/value - A comparison of US refugee education with that of a high-volume European host nation does not yet appear to have been published.
\end{abstract}

Keywords Global education, Refugee education

Paper type Conceptual paper

\section{Introduction}

In recent decades, economic globalization and political instability created great movement among people across the globe. Last year alone, 65 million people were "forcibly" displaced, the highest number since Second World War, and four times more than in 2005 (United Nations Refugee Agency, 2016). Globalization has led some to "self-outsource" looking for better economic conditions. This is exemplified by workers from Greece, Romania and Spain to other parts of the European Union, as well as by Central American and Mexican workers legally and illegally crossing into the USA. The resulting diaspora burdens the infrastructures of the host nations where healthcare, housing and education are impacted (Offe, 2016).

(C) R.D. Nordgren. Published in the Journal of Research in Innovative Teaching \& Learning. This article is published under the Creative Commons Attribution (CC BY 4.0) licence. Anyone may reproduce, distribute, translate and create derivative works of this article (for both commercial and non-commercial purposes), subject to full attribution to the original publication and authors. The full terms of this licence may be seen at http://creativecommons.org/licences/by/4.0/legalcode 
JRIT

10,1

What follows is a report of a two-site case study in Sweden that examined the challenges of educating refugees. The review of the literature provides an examination of challenges created by the mass-migration of displaced people, focusing on two receiving nations: Sweden and the USA. The former has the highest per capita acceptance of refugees in Europe: over 160,000 in 2015 with an overall population of 9.3 million (Lane, 2015). The USA, by contrast, has a population of over 320 million and accepted only 70,000 refugees in 2015, but it is a nation with a reputation for being a nation of immigrants and holds great economic and political importance in the world; therefore, making a noteworthy comparison to Sweden. What the literature and this study conclude is that the use of culture competence and relational closeness may be best to address the challenges of educating displaced peoples not only in the USA and Sweden, but across the globe.

\section{Review of the literature}

Integration and assimilation

Refugees are a subcategory of immigrants. According to the US Department of State:

The United States considers for admission as refugees persons of special humanitarian concern who can establish persecution or a well-founded fear of persecution in their home country on account of race, religion, nationality, membership in a particular social group, or political opinion.

With the Incheon Declaration of May 2015, the United Nations has set a goal to "ensure the provision of 12 years of free, publicly funded, equitable quality primary and secondary education" for all by 2030 (United Nations Educational, Scientific and Cultural Organization, n.d.). In order to honor this declaration, it becomes crucial for all host nations to provide refugees with quality educational experiences, especially (but not exclusively) children and adolescents who are five times more likely to not be in school than natives (United Nations Educational, Scientific and Cultural Organization, 2016). Integration into the host nations' dominant culture is viewed by many to be of the utmost importance in ensuring that refugees, and all marginalized people, obtain a quality education (e.g. Salomone, 2010; United Nations High Commissioner on Refugees, 2015).

In general, the main goal of host countries in the past half-century has been to integrate rather than assimilate all immigrants, including refugees (Ewing, 2012; Salomone, 2010). That is, to welcome them into their society and allowing them to keep most, if not all, of the culture that they bring with them. For many years, the Swedes have attempted to integrate immigrants into what they hoped to be an organic culture rather than assimilate them into one that is, and would remain, static. The USA also has stated policy to this effect. These policies, however, are not without opposition as demonstrated by the recent increase in Nativism in both nations (Crouch, 2014; Dooley, 2012).

When comparing Swedish immigration history to that of the USA, it appears that, although sometimes not intended, integration has prevailed for non-European immigrants while European immigrants mostly assimilated into the dominant (Anglo-Saxon) culture (Ewing, 2012; Lindsey et al., 2009). In the late nineteenth and early twentieth centuries, tens of thousands of Swedes emigrated to the USA quickly abandoning their native tongue and many aspects of their culture (Moberg, 2005). Yet, Mexican, Cuban and Puerto Rican immigrants, for example, have not. They have learned English, for the most part, but still use their languages and live much of their cultures (Salomone, 2010). It is quite apparent how Mexican culture has influenced the dominant US culture by visiting the south-west. The same can be said for many Asian immigrants whose cultures have influenced the dominant (Anglo-Saxon) culture. But this was not intentional. Much effort was and has been made to "Americanize" immigrants, to strip them of their cultures, to assimilate them into the dominant culture. Salomone (2010) states that the Americanization of early immigrants (mostly European) was "acculturation" when repressive and xenophobic interests with, 
sometimes, magnanimous desires to aid the new immigrants forced them to lose their cultures in favor of the dominant one (see also Ewing, 2012). Theodore Roosevelt, a noted Nativist, spoke of a crucible that would "turn out people with one flag, one language" (Salomone, 2010, p. 21). This crucible was also known as the "melting pot" theory that was based on a "sentimental view of amalgamation of immigrants" found in Israel Zangwell's 1908 play simply entitled "Melting Pot" (Salomone, 2010, p. 20). The influential educator Elwood Cubberly of Stanford University was one of the leading Nativists of the early twentieth century, someone who feared immigrants would "dilute tremendously our national stock"

(Salomone, 2010, p. 20).

\section{The current state of immigration in Sweden and the USA}

Immigrants and refugees in the USA amounts to about 13 percent of the nation's population (Migration Policy Institute, n.d.) while Sweden's immigrant and refugee population is about 15 percent of its nine million (Sveriges regering, n.d.). The rate of immigration for the Scandinavian nation, however, far exceeds that of the USA which has accepted roughly one million legal immigrants on an annual basis in the twenty-first century. This one million amounts to about 0.3 percent of the US population each year. Sweden, by contrast, accepted 115,000 in 2013 (Sveriges regering, n.d.) which is approximately 1.2 percent of its population or four times the rate of the USA Regarding refugees, the USA received nearly 70,000 in 2014 whereas the figures for Sweden were more than 142,000 in 2014 (World Bank, n.d.) and more than 160,000 in 2015 (Lane, 2015). Sweden not only received twice as many refugees but also received them at a rate that was 75 times that of the USA.

As media reports indicate, the massive influx of refugees into Europe has caused much strife throughout the continent. This influx, as one might deduce, causes great strain on host societies, both economically and politically (Knight et al., 2009). The civil war in Syria has been the catalyst for the most recent increases in refugees but Sweden, as mentioned previously, has been a magnet for refugees for decades, accepting Eastern-Bloc citizens fleeing Soviet domination following WW II, Bosnians in the 1990s, and Iraqis during the start of the US-led invasion of that country in 2003 (Swedish Institute, n.d.).

Politically, the immigration/refugee dilemma came to the forefront in the 2006 Swedish national elections when a center-right coalition promised to curtail immigration (Scrutton and Ahlander, 2013). In 2010, the Sweden Democrats, historically a very minor party with Nativist beliefs with member connected to neo-Nazism (Crouch, 2014), earned seats in parliament when they garnered 5 percent of the national vote and even more seats in 2014 when they received 10 percent of the vote. Their key objective is to reduce immigration and, by doing so, they hope to keep Sweden "Swedish" (Shapiro, 2015).

Despite a thoughtful attempt to integrate immigrants into the (intentionally) malleable Swedish culture, problems persist. The author found this in 2013 as a by-product of his research of progressive Swedish schooling practices, replicating his 2001 study. The topic of how to meet the needs of immigrant students as well as how to integrate them into the community was brought up time and again in interviews with teachers and students (Nordgren, 2013). Recent media reports support these findings. For instance, the Øresund Bridge between Malmo and Copenhagen has found itself under higher security (CXC Global, 2016), a New Year's Eve celebration in Stockholm was marred by reports of molestation by immigrants (Shapiro, 2015), and several nights of unrest leading to burned cars and buildings outside of Stockholm (The Guardian, 2013). Despite these conflicts, Swedish people agree that they should continue to support refugees and keep their borders open to them, but it is understood that new policies must be put in place to address these struggles (Shapiro, 2015). 
JRIT

10,1

\section{Education of refugee populations}

Schooling of refugees offers unique challenges to educators; most crucial may be integration into the dominant culture. Oh (2012) believes, historically, refugee education was to assimilate rather than integrate: "Formal education has characteristically been employed to promulgate, reify and legitimize certain constructions of collective social identity be they religious, ethnic, political, ideological, cultural, or social class" (pp. 73-74). While in agreement, Dooley (2012) asserts that refugees must be positioned to become intellectual class members in order for them to be truly integrated. As many refugees and immigrants bring with them much-needed skills and high levels of education, becoming a member of the intellectual class would be part of the natural order of events, it would seem. However, Dooley contends, xenophobia and institutionalized racism can inhibit or even stop this positioning. Another obstacle is the mismatch of credentialing which can find a physician from Syria, for example, unable to practice medicine in her accepting nation. Oftentimes, refugees not only come from poverty, but were educated in a "pedagogy of poverty" of mere transmission of facts rather than high-cognitive learning; this not only hinders class advancement but can be perplexing obstacle to educators (see Haberman, 1991; Zhao, 2009, 2012).

A way to address these challenges is to provide learning environments that are not only accepting of the immigrants' culture but invites it, actively seeking their input. Kirova (2012) offers support to Pierre Bourdieu's assertion that people can suffer a "negative internalization" when their own cultural capital has little value in the dominant culture. By actively seeking ways in which the capital that immigrants bring into the school (and society) then integration will more likely occur. Kirova goes on to recommend that schools show value for the parents' knowledge, as well as the students', and to allow them to maintain their own language as the Swedes seem determined to do (something that is still quite a matter of debate in the USA (Grovum, 2014)).

Educators of special needs students in the USA have long supported integration of diverse learners into the "mainstream" (Osgood, 2005). This has also been found to be effective for immigrants and refugees, supporting what Banki (2012) terms "Relational Closeness," a concept and strategy used in "Intergroup Contact Theory." Relational closeness seeks to bring natives and refugees closer together, relieving tension that will likely exist. When managed correctly, research suggests it improves individual cooperation among all parties (Forbes, 1997).

\section{Cultural competence}

In order for integration to be successful, ensuring schools have "culturally competent" teachers and administrators is essential according to some scholars (e.g. Banks, 2002; Diller and Moule, 2004). Cultural competence is generally defined as the ability of one to accept the behaviors and beliefs of someone from another culture as well as one's ability to adapt to an alien culture (Gutierrez and Rogoff, 2003; Lindsey et al., 2009). By empathizing with the students, and having the willingness to gain an understanding of their cultures and 
situations, teachers will be more capable and willing to meet the educational as well as social-emotional needs of the students (Diller and Moule, 2004). The Swedes have a great history of tolerance, a willingness to accept differences among its native people as well as immigrants (Lane, 2015). This is an important attribute when one wishes to increase cultural competence (Gutierrez and Rogoff, 2003).

Effective teachers create strong relationships with their students to improve trust as well as communication (Goldstein, 1999); relationship building and communication are key attributes to cultural competence (Gutierrez and Rogoff, 2003; Lindsey et al., 2009). Integration would seem to benefit greatly from a population with high cultural competence where differences are accepted and, perhaps, even celebrated for the diversity they bring to the culture. Educators with high cultural competence can help students integrate into the school culture, enriching the educational experiences of all students (Banks, 2002; Diller and Moule, 2004). Close relationships between teachers and students not only improves the learning culture (McGrath, 1998) but also empowers students to become a life-long learners, striving to improve their lots in life and, thus, providing stronger contributions to the economy and society (Darling-Hammond, 2010; Nieto, 2004). Although refugees ostensibly are temporary immigrants, returning to their home nation when is safe to do so, only about 15 percent do return, according to the United Nations Refugee Agency (n.d.). Given that as many as 85 percent of the world's 16 million refugees will remain in their host nation, it seems it is incumbent upon host nations to ensure that these populations can be successfully integrated.

\section{Methods}

In an attempt to determine if two schools in small Swedish communities impacted by large numbers of refugees were meeting the needs of refugee students, a two-site case study was developed and implemented. This study proposed to answer the overarching question:

- What impact does the recent influx of refugees have on schooling process in these two rural communities?

Based on the review of relevant literature pertaining to the research question and sub-questions, the researcher adopted a mixed-methods approach consisting of surveys for teachers and students; interviews of teachers, students and principals; and a document review (national policies pertaining to immigrant and refugee education). The surveys and interview questions are found in the Appendices section.

The settings were two, small towns in Northern Sweden each with a significant number of immigrants and refugees (numbers of refugees are assigned to each community based on its population as part of a quota system (Swedish Institute, n.d.)). Swedish education is controlled locally by municipalities or "kommunerna." The towns in which this study took place each had about 2,000 inhabitants and were situated in two separate kommunerna serving multiple small towns. The school sites were secondary schools serving both high school-aged and adult populations of refugees but shared facilities (e.g. cafeteria) with traditional schools.

Both principals were interviewed in person and via e-mail. Teachers in Kommun A were interviewed en masse with 17 in attendance in what was also a presentation of the research proposal. These teachers were invited to participate in e-mail interviews. Students at Kommun A were interviewed in a small group. At Kommun B, teachers were interviewed individually $(n=3)$ but all were invited to the e-mail interview. These interview data were analyzed qualitatively seeking themes and patterns in responses as well as novel responses requiring further investigation.

Surveys were conducted using SurveyMonkey where all teachers and students were sent a link to the survey via e-mail. Participants were given a 30-day window to respond, after which all data were collected and analyzed both quantitatively and qualitatively. 


\section{JRIT 10,1}

\section{Findings}

In an attempt to answer $R Q 1$ was deemed important to also examine ancillary questions the researcher hoped to get answered by the research:

$R Q 1$. What impact does the recent influx of refugees have on schooling in two rural communities in Sweden?

This section reports the findings as they relate to both the primary and ancillary questions.

\section{Primary question}

The greatest impact seems to be in the local funds needed to compensate for a perceived lack of funding from the federal government to educate refugees. One principal commented that a school received less per refugee than it would for a native-born Swede. The schools were meant for transitioning refugee students into the Swedish system for natives. With inadequate funding, an effective transition where the student is fully capable of the challenges of the regular school could be difficult to achieve. The transition to a regular school as well as into the Swedish society, can be improved with more opportunities for interactions with native Swedes, other than teachers. The principals, teachers and students, themselves, all realize this and want to see the communities offer more opportunities.

\section{Ancillary questions}

What impact does this influx of refugees have on teachers' practice in the classroom? Both schools served refugees, only (although they shared facilities with regular schools) so the actual practices of the teachers was focused totally on their specific needs. Some teachers had training at the university specific to teaching Swedish as a Second Language (svenska som andraspråk) (or SSA). Others have taken professional development to teach SSA students. Still others are in need of this professional development and are seeking to get it.

What impact does this influx of refugees have on administrators' work in the schools and districts? The two principals were hired to lead schools who serve refugees. The greatest concern was funding to ensure the students' needs are met, but they are also keenly aware that more professional development is needed for teachers. Both principals are highly collaborative and use a democratic style of leadership (supported by teachers' comments about their principals as well as culled from the interviews with the principals, themselves). It was apparent that both principals were flexible and were willing to take risks. At one school, scheduling was changed up as often as monthly in order to ensure the teachers and students were receiving the time necessary for each subject area.

How are teachers addressing the needs of recent refugees? Mostly through trial and error, it seems. Some have university degrees in SSA, and others have some training in it, while others have no such training or education. They must rely on their basic teacher education to ensure that proper pedagogical practices are in place. What both schools have found (through trial and error) is that individualized learning is necessary. Each student comes to the schools with different levels of Swedish language acquisition as well as knowledge and skills in various subject matters. In response, teachers have formed individualized plans for the students, and utilized small group and one-on-one instruction for the bulk of their daily practices.

How are administrators addressing the needs of recent refugees? As mentioned above, the principals are seeking local funds from their respective communities to bolster the federal funds which are not meeting the needs of the refugees. Additionally, they are using flexible scheduling and democratic structures to empower the teachers so that they can utilize individualized instruction.

How are the communities addressing the needs of recent refugees? Each community is offering additional funding to the federal funding, and they are supervising housing for 
unaccompanied minor and even adult students. Great care is taken to ensure that someone who knows each refugee's language and culture is available to supervise this housing, although the supervisors do not live in the housing if the students are adults.

Do refugee students believe their education needs are being met? As far as the schools are concerned, then yes, they do believe their needs are being met. They had many accolades for their teachers and their schools. The only request they made was to have more "språk kaffe" opportunities in the communities where they could mingle with Swedes to become more fluent in the language and to better immerse themselves in the culture.

In short, the schools in this study seemed to be attempting "best practices" in meeting the educational needs of their diverse groups of refugee students as reported in the literature; that is, cultural competence and relational closeness. As described in the next section, these educators appeared aware of the need for these two innovate practices/concepts, yet understood that they were falling short in both. At least 16 languages are spoken by these students as their primary mode of communication, ostensibly learning Swedish as rapidly as possible so as to be ready to integrate into Swedish society. Furthermore, those with secondary school status must quickly learn other schooling content as well as Swedish. The needs of the students to learn Swedish (and other subjects, if they apply) and to better integrate into society can be improved with more opportunities to interact with native Swedes. In addition, the data reported a need for more funding for education of refugees, education that would appear to be more expensive, given the unique needs of this population, but the schools actually receive less to educate them than they would if they were native Swedes.

\section{Discussion}

The data and the literature point to the need for increased integration of refugee students into the Swedish culture. A concern mentioned by many of the study's participants was what appears to be a lack of relational closeness as espoused by Banki (2012). Both refugee integration and education literature suggest increased cultural competence among teachers can increase educational success for refugees and improved chances of integration by increasing relational closeness (Banki, 2012; Dooley, 2012; Kirova, 2012). The Swedes have been attempting to increase cultural competence on a national level beginning in their school systems for some time: the Swedish National Curriculum for Compulsory Education has explicitly stated the importance of learning to be tolerant for decades (Skolverket, 1994). The USA, by contrast, has no national school system but instead has 50 autonomous state systems and 14,500 fairly autonomous district systems. Therefore, no cohesive, unified policy or movement to increase cultural competence currently exists in the USA It should be noted that enacting nationwide educational change in the USA is onerous, if not impossible, as demonstrated by the resistance to such "national" reforms as No Child Left Behind and The Common Core. The US federal government contributes, on average, only 8 percent of a school district's operating expenses (United States Department of Education, n.d.) so there may be little incentive to buy into such movements, even those mandated by law (Hargreaves and Shirley, 2012). It should also be noted that with the increased political polarization in the USA, anything brought forward by a presidential administration will likely have 50 percent of Washington, DC and state-house politicians against the measure (Ravitch, 2013). As noted previously, even the Swedes with a national movement toward cultural competence are experiencing increased Nativism. A groundswell of tolerance would need to be seen in both nations in order for cultural competence to increase. This groundswell may come from increased interactions with the native and refugee populations as familiarity has been shown to decrease conflict (Rubenfeld and Clement, 2012).

The turmoil caused by massive growth in displaced people does not seem as if it will subside in the near future. Even if Nativism leads to more anti-immigration measures taken by both the Swedes and Americans, the world will still be forced to address this phenomenon. Those nations 
JRIT 10,1

with mass emigration due to social and political conflict and/or economic deprivation (e.g. Syria, Iraq, Afghanistan, Somalia, Mexico and Eritrea) show no signs of improving their political and economic situations (Offe, 2016); and host nations cannot realistically keep "unwanted" immigrants from finding a way to their lands, despite the growing Nativist movement. As the diaspora increases, it becomes crucial for nations such as Sweden and the US to improve educational services for refugees, both P-12 aged students as well as adults. Refugees and all immigrants must contribute to both the economies and the democratic processes of their host nations in order to maintain economic prosperity and social stability in these lands (Salomone, 2010).

\section{Conclusion}

This paper provides a synopsis of the current state of refugee education in both Sweden and the USA, and an overview of the importance of integration of refugees into their host nations' societies; and anchored by findings from a two-site case study conducted in Northern Sweden. A major concern stemming from the case study data were a lack of integration into the small communities due to lack of opportunities, mirroring the literature. Two possible solutions offered were to increase opportunities for interaction between native and refugee populations (relational closeness); and bolster funding for the education of refugee school-age children and adolescents, and adults so that effective strategies and environment described in the literature can be put into place by effectively trained educators. These solutions could improve the cultural competence among all peoples in both nations, better enabling the two countries to provide economically and socially sustainable environments for all of their inhabitants.

As the diaspora of displaced peoples continues to exist and expand across the world, education of refugees becomes vital for all those directly and indirectly affected, including nation states. With no short-term possibility of their returning to war-torn nations such as Syria, Iraq, Afghanistan and Somalia, it is incumbent upon the host nations to provide educational opportunities for the refugees so that they can contribute to the economic and social wellbeing of those nations as well as provide them the opportunity to these people to live in a relatively safe and harmonious land.

\section{References}

Banki, S. (2012), "Refugees as educators: the potential for positive impact on educational systems", in McCarthy, F.E. and Vickers, M.G. (Eds), Refugee and Immigrant Students: Achieving Equity in Education, Information Age Publishing, Charlotte, NC, pp. 43-64.

Banks, J.A. (2002), "Race, knowledge construction, and education in the USA: lessons from history", Race, Ethnicity and Education, Vol. 5 No. 1, pp. 7-27.

Coates, D. (2011), "The strengths and weaknesses of American exceptionalism”, Social Europe, May 2, available at: www.socialeurope.eu/2011/05/the-strengths-and-weaknesses-of-american-exceptionalism/

Crouch, D. (2014), “The rise of the anti-immigrant Sweden Democrats: 'We don't feel at home any more, and it's their fault', The Guardian, December 13, available at: www.theguardian.com/world/ 2014/dec/14/sweden-democrats-flex-muscles-anti-immigrant-kristianstad

CXC Global (2016), "Security increases at the Øresund Bridge", January 16, available at: http://cx cglobalemea.com/security-increases-at-the-oresund-bridge/

Darling-Hammond, L. (2010), The Flat World and Education: How America's Commitment to Equity will Determine our Future, Teachers College Press, New York, NY.

Diller, J.V. and Moule, J. (2004), Cultural Competence: A Primer for Educators, Wadsworth, New York, NY.

Dooley, K. (2012), "Positioning refugee students as intellectual class members", in McCarthy, F.E. and Vickers, M.G. (Eds), Refugee and Immigrant Students: Achieving Equity in Education, Information Age Publishing, Charlotte, NC, pp. 3-20. 
Ewing, W.A. (2012), "Opportunity and exclusion: a brief history of US immigration policy”, paper published by the American Immigration Council, Washington, DC, available at: www. immigrationpolicy.org/sites/default/files/docs/opportunity_exclusion_011312.pdf

Forbes, H.D. (1997), Ethnic Conflict: Commerce, Culture, and the Contact Hypothesis, Yale University Press, New Haven, CT.

Goldstein, L. (1999), "The relational zone: the role of caring relationships in the co-construction of mind", American Educational Research Journal, Vol. 36 No. 3, pp. 647-673.

Grovum, J. (2014), “The English-only debate heats up again”, Stateline, August 8, available at: www. governing.com/news/headlines/the-english-only-debate-heats-up-again.html

Gutierrez, K.D. and Rogoff, B. (2003), "Cultural ways of learning: individual traits or repertoires of practice?”, Educational Researcher, Vol. 32 No. 5, pp. 19-25.

Haberman, M. (1991), "The pedagogy of poverty versus good teaching”, Phi Delta Kappan, Vol. 73 No. 4, pp. 290-294.

Habermas, J. (2016), "Core Europe to the rescue: a conversation with Jürgen Habermas about Brexit and the EU crisis", Social Europe, July 12, available at: www.socialeurope.eu/2016/07/core-europe-tothe-rescue/

Hargreaves, A. and Shirley, D. (2012), The Global Fourth Way: The Quest for Educational Excellence, Corwin, Thousand Oaks, CA.

Kirova, A. (2012), "Creating shared learning spaces: an intercultural, multilingual early learning program for preschool children", in McCarthy, F.E. and Vickers, M.G. (Eds), Refugee and Immigrant Students: Achieving Equity in Education, Information Age Publishing, Charlotte, NC, pp. 21-42.

Knight, G.P., Jacobson, R.P., Gonzales, N.A., Roosa, M.W. and Saenz, D.S. (2009), “An evaluation of the psychological research on acculturation and enculturation processes among recently immigrating populations", in Dalla, R.L., Defrain, J., Johson, J. and Abbott, D.A. (Eds), Strengths and Challenges of New Immigrant Families: Implications for Research, Education, Policy, and Service, Lexington Books, Lanham, MD, pp. 9-32.

Lane, E. (2015), "How Sweden tries to assimilate its influx of refugees", BBC News, September 12, available at: www.bbc.com/news/business-34261065 (accessed January 14, 2016).

Liasson, M. (2015), "Nativism and economic anxiety fuel Trump's populist appeal”, National Public Radio, September 21, available at: www.npr.org/sections/itsallpolitics/2015/09/04/437443401/ populist-movement-reflected-in-campaigns-of-sanders-and-trump

Lindsey, R.B., Robins, K.N. and Terrell, R.D. (2009), Cultural Proficiency: A Manual for School Leaders, 3rd ed., Sage, Thousand Oaks, CA.

McGrath, V.R. (1998), "The educator's dilemma: loss of trust, familiarity, and self", The Educational Forum, Vol. 62 No. 4, pp. 329-332.

Migration Policy Institute (n.d.), "Frequently requested statistics on immigrants and immigration in the United States", available at: www.migrationpolicy.org/article/frequently-requested-statisticsimmigrants-and-immigration-united-states/

Moberg, V. (2005), A History of the Swedish People, Volume II: From Renaissance to Revolution (Trans. by Austin, A.B.), University of Minnesota Press, St Paul, MN.

Nieto, S. (2004), Affirming Diversity: The Sociopolitical Context of Multicultural Education, 4th ed., Longman, White Plains, NY.

Nordgren, R.D. (2013), "Democracy, trust, responsibility, and global workforce competence: a case study revisited", Report to Katrineholm Kommun.

Offe, C. (2016), "For a robust policy of integration of refugees", Social Europe, March 8, available at: www.socialeurope.eu/2016/03/robust-policy-integration-refugees/

Oh, S.-A. (2012), "Identity and inclusion: education in refugee camps in Thailand", in McCarthy, F.E. and Vickers, M.G. (Eds), Refugee and Immigrant Students: Achieving Equity in Education, Information Age Publishing, Charlotte, NC, pp. 65-88. 
JRIT 10,1

Osgood, R.L. (2005), The History of Inclusion in the United States, Gallaudet University Press, Washington, DC.

Ravitch, D. (2013), Reign of Error: The Hoax of the Privatization Movement and the Danger of America's Public Schools, Random House, New York, NY.

Rubenfeld, S. and Clement, R. (2012), "Intercultural conflict and mediation: an intergroup perspective", Language Learning, Vol. 62 No. 4, pp. 1205-1230.

Salomone, R.C. (2010), True American: Language, Identity, and the Education of Immigrant Children, Harvard University Press, Cambridge, MA.

Scrutton, A. and Ahlander, J. (2013), "In bastion of tolerance Sweden, immigration is questioned", April 17, available at: www.reuters.com/article/us-sweden-immigration-idUSBRE93G06G20130417

Shapiro, A. (2015), "Sweden's immigrant influx unleashes a backlash", National Public Radio, February 6, available at: www.npr.org/sections/parallels/2015/02/05/384096505/swedens-immigrant-influxunleashes-a-backlash

Skolverket (1994), Läroplan 1994 för obligatoriska skolan, Skolverket, Stockholm.

Sveriges regering (n.d.), "Sweden and migration", available at: https://sweden.se/migration/\#2015

The Guardian (2013), "Swedish riots rage for fourth night", The Guardian, agencies in Stockholm, May 23, available at: www.theguardian.com/world/2013/may/23/swedish-riots-stockholm

United Nations Educational, Scientific and Cultural Organization (2016), "Policy Paper 26: Provide education to all forcibly displaced persons", May, available at: http://unesdoc.unesco.org/ images/0024/002448/244847E.pdf

United Nations Educational, Scientific and Cultural Organization (n.d.), "Inchon declaration: education 2030: towards an inclusive and equitable quality education and lifelong learning for all", available at: www.uis.unesco.org/Education/Documents/education_2030_incheon_declaration_en.pdf

United Nations High Commissioner on Refugees (2015), "Education issue brief 1: education and protection", July, available at: www.unhcr.org/en-us/publications/education/560be0dd6/ education-brief-1-education-protection.html

United Nations Refugee Agency (2016), "Global forced displacement hits record high”, 20 June, available at: www.unhcr.org/en-us/news/latest/2016/6/5763b65a4/global-forced-displacementhits-record-high.html

United Nations Refugee Agency (n.d), "United Nations high commissioner on refugees world population statistics database", available at: http://popstats.unhcr.org/en/overview\#_ga $=1.210$ 597397.1474147586.1478554158

United States Department of Education (n.d.), "10 facts about education funding”, available at: www2. ed.gov/about/overview/fed/10facts/index.html?exp

World Bank (n.d.), "Refugee population by country or territory of asylum", available at: http://data. worldbank.org/indicator/SM.POP.REFG

Zhao, Y. (2009), Catching up or Leading the Way: American Education in the Age of Globalization, ASCD, Alexandria, VA.

Zhao, Y. (2012), World Class Learners: Educating Creative and Entrepreneurial Students, Corwin, Thousand Oaks, CA.

\section{Further reading}

Hstry.com (n.d.), "A history of immigration in the US", available at: https:/edu.hstry.co/timeline/ahistory-of-immigration-in-the-usa

Nordgren, R.D. (2016), "Meeting the educational needs of refugees in two Swedish communities", unpublished research report.

United States Department of State (n.d.), "Appendix G: overview of US refugee policy”, available at: www.state.gov/j/drl/rls/irf/2001/5562.htm 


\begin{tabular}{|c|c|c|c|c|c|c|}
\hline Item & Responses & Responses & Responses & Responses & Responses & \\
\hline $\begin{array}{l}1 \text { How many immigrant or refugee students do you } \\
\text { teach? }\end{array}$ & None, zero & $\begin{array}{l}\text { Fewer than } \\
5\end{array}$ & $6-10$ & $11-15$ & 16 or more & 89 \\
\hline $\begin{array}{l}2 \text { How many of your immigrant students do you } \\
\text { think arrived in Sweden after } 1 \text { January 2015? }\end{array}$ & None, zero & $\begin{array}{l}\text { Fewer than } \\
5\end{array}$ & $6-10$ & $11-15$ & 16 or more & \\
\hline $\begin{array}{l}3 \text { For example, if you have students you know were } \\
\text { born in Sweden, Syria, and Russia, your answer } \\
\text { would be } 3\end{array}$ & 1 & 2 & 3 & 4 & 5 or more & \\
\hline $\begin{array}{l}4 \text { What languages other than Swedish and English } \\
\text { do your students speak? }\end{array}$ & $\begin{array}{l}\text { Please } \\
\text { write }\end{array}$ & $\begin{array}{l}\text { your } \\
\text { answers }\end{array}$ & $\begin{array}{l}\text { in these } \\
\text { boxes }\end{array}$ & & & \\
\hline $\begin{array}{l}5 \text { On average, how long have your REFUGEE } \\
\text { students lived in SWEDEN prior to coming into } \\
\text { your classroom? }\end{array}$ & $\begin{array}{l}\text { Less than } \\
6 \text { months }\end{array}$ & $\begin{array}{l}6 \text { months } \\
\text { to } 1 \text { year }\end{array}$ & $\begin{array}{l}1 \text { year to } \\
2 \text { years }\end{array}$ & $\begin{array}{l}2 \text { years to } \\
3 \text { years }\end{array}$ & $\begin{array}{l}\text { More than } \\
3 \text { years }\end{array}$ & \\
\hline $\begin{array}{l}6 \text { On average, how long have your REFUGEE } \\
\text { students lived in your COMMUNITY prior to } \\
\text { coming to your classroom? } \\
\text { Please answer items } 7 \text { through } 17 \text { with the } \\
\text { answer that best fits your present beliefs or } \\
\text { thinking about each statement }\end{array}$ & $\begin{array}{l}\text { Less than } \\
6 \text { months }\end{array}$ & $\begin{array}{l}6 \text { months } \\
\text { to } 1 \text { year }\end{array}$ & $\begin{array}{l}1 \text { year to } \\
2 \text { years }\end{array}$ & $\begin{array}{l}2 \text { years to } \\
3 \text { years }\end{array}$ & $\begin{array}{l}\text { More than } \\
3 \text { years }\end{array}$ & \\
\hline $\begin{array}{l}7 \text { Teaching first-generation Swedes is more } \\
\text { difficult than teaching native-born Swedes }\end{array}$ & $\begin{array}{l}\text { Strongly } \\
\text { disagree } \\
1\end{array}$ & $\begin{array}{l}\text { Disagree } \\
2\end{array}$ & $\begin{array}{l}\text { Agree } \\
3\end{array}$ & $\begin{array}{l}\text { Strongly } \\
\text { agree } \\
4\end{array}$ & $\begin{array}{l}\text { No } \\
\text { opinion }\end{array}$ & \\
\hline $\begin{array}{l}8 \text { I am in need of more support to help me teach my } \\
\text { immigrant students }\end{array}$ & $\begin{array}{l}\text { Strongly } \\
\text { disagree } \\
1\end{array}$ & $\begin{array}{l}\text { Disagree } \\
2\end{array}$ & Agree 3 & $\begin{array}{l}\text { Strongly } \\
\text { agree } \\
4\end{array}$ & $\begin{array}{l}\text { No } \\
\text { opinion }\end{array}$ & \\
\hline $\begin{array}{l}9 \mathrm{My} \text { immigrant students receive sufficient support } \\
\text { services prior to coming to my classroom }\end{array}$ & $\begin{array}{l}\text { Strongly } \\
\text { disagree } \\
1\end{array}$ & $\begin{array}{l}\text { Disagree } \\
2\end{array}$ & $\begin{array}{l}\text { Agree } \\
3\end{array}$ & $\begin{array}{l}\text { Strongly } \\
\text { agree } \\
4\end{array}$ & $\begin{array}{l}\text { No } \\
\text { opinion }\end{array}$ & \\
\hline $\begin{array}{l}10 \text { My immigrant students receive sufficient support } \\
\text { services when they are in my classroom }\end{array}$ & $\begin{array}{l}\text { Strongly } \\
\text { disagree } \\
1\end{array}$ & $\begin{array}{l}\text { Disagree } \\
2\end{array}$ & $\begin{array}{l}\text { Agree } \\
3\end{array}$ & $\begin{array}{l}\text { Strongly } \\
\text { agree } \\
4\end{array}$ & $\begin{array}{l}\text { No } \\
\text { opinion }\end{array}$ & \\
\hline $\begin{array}{l}11 \text { I received sufficient education at my university to } \\
\text { teach immigrant students }\end{array}$ & $\begin{array}{l}\text { Strongly } \\
\text { disagree } \\
1\end{array}$ & $\begin{array}{l}\text { Disagree } \\
2\end{array}$ & $\begin{array}{l}\text { Agree } \\
3\end{array}$ & $\begin{array}{l}\text { Strongly } \\
\text { agree } \\
4\end{array}$ & $\begin{array}{l}\text { No } \\
\text { opinion }\end{array}$ & \\
\hline $\begin{array}{l}12 \text { I received sufficient education from my school to } \\
\text { teach immigrant students }\end{array}$ & $\begin{array}{l}\text { Strongly } \\
\text { disagree } \\
1\end{array}$ & $\begin{array}{l}\text { Disagree } \\
2\end{array}$ & $\begin{array}{l}\text { Agree } \\
3\end{array}$ & $\begin{array}{l}\text { Strongly } \\
\text { agree } \\
4\end{array}$ & $\begin{array}{l}\text { No } \\
\text { opinion }\end{array}$ & \\
\hline $\begin{array}{l}13 \text { My school sufficiently supports immigrant } \\
\text { students }\end{array}$ & $\begin{array}{l}\text { Strongly } \\
\text { disagree } \\
1\end{array}$ & $\begin{array}{l}\text { Disagree } \\
2\end{array}$ & $\begin{array}{l}\text { Agree } \\
3\end{array}$ & $\begin{array}{l}\text { Strongly } \\
\text { agree } \\
4\end{array}$ & $\begin{array}{l}\text { No } \\
\text { opinion }\end{array}$ & \\
\hline $\begin{array}{l}14 \text { My community sufficiently supports immigrant } \\
\text { students }\end{array}$ & $\begin{array}{l}\text { Strongly } \\
\text { disagree } 1\end{array}$ & Disagree 2 & Agree 3 & $\begin{array}{l}\text { Strongly } \\
\text { agree } 4\end{array}$ & $\begin{array}{l}\text { No } \\
\text { opinion }\end{array}$ & \\
\hline $\begin{array}{l}15 \text { My community sufficiently supports the parents } \\
\text { of immigrants to ensure that their children are } \\
\text { prepared for school }\end{array}$ & $\begin{array}{l}\text { Strongly } \\
\text { disagree } \\
1\end{array}$ & $\begin{array}{l}\text { Disagree } \\
2\end{array}$ & $\begin{array}{l}\text { Agree } \\
3\end{array}$ & $\begin{array}{l}\text { Strongly } \\
\text { agree } \\
4\end{array}$ & $\begin{array}{l}\text { No } \\
\text { opinion }\end{array}$ & \\
\hline $\begin{array}{l}16 \text { The Ministry of Education (Skolverket) } \\
\text { sufficiently supports immigrant students }\end{array}$ & $\begin{array}{l}\text { Strongly } \\
\text { disagree } \\
1\end{array}$ & $\begin{array}{l}\text { Disagree } \\
2\end{array}$ & $\begin{array}{l}\text { Agree } \\
3\end{array}$ & $\begin{array}{l}\text { Strongly } \\
\text { agree } \\
4\end{array}$ & $\begin{array}{l}\text { No } \\
\text { opinion }\end{array}$ & Table AI \\
\hline $\begin{array}{l}17 \text { The Swedish national government (Sveriges } \\
\text { regering) sufficiently supports immigrants to } \\
\text { ensure that their children are prepared for school }\end{array}$ & $\begin{array}{l}\text { Strongly } \\
\text { disagree } \\
1\end{array}$ & $\begin{array}{l}\text { Disagree } \\
2\end{array}$ & $\begin{array}{l}\text { Agree } \\
3\end{array}$ & $\begin{array}{l}\text { Strongly } \\
\text { agree } \\
4\end{array}$ & $\begin{array}{l}\text { No } \\
\text { opinion }\end{array}$ & $\begin{array}{r}\text { Survey sent } \\
\text { to teachers via } \\
\text { SurveyMonkey }\end{array}$ \\
\hline
\end{tabular}




\begin{tabular}{|c|c|c|c|c|}
\hline Item & Responses & Responses & Responses & Responses \\
\hline $\begin{array}{l}1 \text { I was not born in } \\
\text { Sweden }\end{array}$ & Yes & No & & \\
\hline $\begin{array}{l}2 \text { I was born in } \\
\text { Sweden, but my } \\
\text { parents were not }\end{array}$ & $\begin{array}{l}\text { Yes, I was born in } \\
\text { Sweden, but my } \\
\text { parents were not }\end{array}$ & $\begin{array}{l}\text { No, I was born in } \\
\text { Sweden and so } \\
\text { were my parents }\end{array}$ & $\begin{array}{l}\text { One of my parents } \\
\text { was born in } \\
\text { Sweden, the other } \\
\text { was not }\end{array}$ & \\
\hline 3 I began living in & Yes & No & & \\
\hline
\end{tabular}

Sweden after 1

January 2015

Please answer items 4 through 10

with the answer that

best fits your present beliefs or thinking

4 I speak good Swedish

5 I believe speaking good Swedish is important

6 I speak good English

7 I believe speaking good English is important

8 I enjoy having people who were born in other nations in my classes

9 I learn better because I have students from other nations in $\mathrm{my}$ classes

10 I could learn better if I did not have students from other nations in my classes

11 I have friends who were born in other nations

Table AII.

Survey sent to students via SurveyMonkey
Yes, I strongly agree with this statement 1

Yes, I strongly agree with this statement

$$
1
$$

Yes, I strongly agree with this statement 1

Yes, I strongly agree with this statement 1 Yes, I strongly agree with this statement 1

Yes, I strongly agree with this statement 1

Yes, I strongly agree with this statement 1

Yes, I have many friends born in nations other than Sweden 1
Yes, I agree with this statement 2

Yes, I agree with this statement 2

Yes, I agree with this statement 2

Yes, I agree with this statement 2

Yes, I agree with this statement 2

Yes, I agree with this statement 2

Yes, I agree with this statement 2

Yes, I have some friends born in nations other than Sweden 2
No, I disagree with No, I strongly this statement disagree with this 3 statement 4

No, I disagree with No, I strongly this statement disagree with this 3 statement 4

No, I disagree with No, I strongly this statement disagree with this 3 statement 4

No, I disagree with No, I strongly this statement disagree with this 3 statement 4

No, I disagree with No, I strongly this statement disagree with this 3 statement 4

No, I disagree with No, I strongly this statement disagree with this 3 statement 4

No, I disagree with No, I strongly this statement disagree with this statement 4

No, I do not have any friends born in nations other than Sweden 3 


\begin{tabular}{|c|c|c|c|c|c|c|}
\hline & Item & Responses & Responses & Responses & Responses & ugee \\
\hline 12 & $\begin{array}{l}\text { I work on school } \\
\text { assignments with } \\
\text { students who were } \\
\text { born in other } \\
\text { nations }\end{array}$ & $\begin{array}{l}\text { I often work with } \\
\text { students who were } \\
\text { born in other } \\
\text { nations } \\
1\end{array}$ & $\begin{array}{l}\text { I sometimes work } \\
\text { on school } \\
\text { assignment with } \\
\text { students who were } \\
\text { born in other } \\
\text { nations } \\
2\end{array}$ & $\begin{array}{l}\text { I never work with } \\
\text { students who were } \\
\text { born in other } \\
\text { nations } \\
3\end{array}$ & & 91 \\
\hline 13 & $\begin{array}{l}\text { I spend time with } \\
\text { students who were } \\
\text { born in other } \\
\text { nations when I am } \\
\text { not in school }\end{array}$ & $\begin{array}{l}\text { I often spend time } \\
\text { with students who } \\
\text { were born in other } \\
\text { nations when I am } \\
\text { not in school } \\
1\end{array}$ & $\begin{array}{l}\text { I sometimes spend } \\
\text { time with students } \\
\text { who were born in } \\
\text { other nations when } \\
\text { I am not in school } \\
2\end{array}$ & $\begin{array}{l}\text { I never spend time } \\
\text { with students who } \\
\text { were born in other } \\
\text { nations when I am } \\
\text { not in school } \\
3\end{array}$ & & \\
\hline 14 & $\begin{array}{l}\text { I would like to learn } \\
\text { more about the } \\
\text { foreign nations from } \\
\text { which students in } \\
\text { my school were } \\
\text { born }\end{array}$ & $\begin{array}{l}\text { Yes, I would like to } \\
\text { learn more about } \\
\text { these nations } \\
1\end{array}$ & $\begin{array}{l}\text { No, I would not like } \\
\text { to learn more about } \\
\text { these nations } \\
2\end{array}$ & & & \\
\hline 15 & $\begin{array}{l}\text { My school is a good } \\
\text { place to learn }\end{array}$ & $\begin{array}{l}\text { Yes, I strongly } \\
\text { agree with this } \\
\text { statement } \\
1\end{array}$ & $\begin{array}{l}\text { Yes, I agree with } \\
\text { this statement } \\
2\end{array}$ & $\begin{array}{l}\text { No, I disagree with } \\
\text { this statement } \\
3\end{array}$ & $\begin{array}{l}\text { No, I strongly } \\
\text { disagree with this } \\
\text { statement } \\
4\end{array}$ & Table A \\
\hline
\end{tabular}

\section{Appendix 3. Interview questions}

\section{Teachers}

- Do immigrant students whose parents had jobs coming into Sweden receive better educational services than refugee students? Should they?

- What are the main concerns with teaching immigrant students?

- What positive impact have immigrant students had in your classroom and/or school?

- What support, if any, have you been given to effectively teach immigrant students?

- How have your interactions been with the parents or guardians of immigrant students?

- Are immigrant students adequately served in your school? Your community?

- What do you believe would improve the educational attainment of immigrant students?

- What else would you like to tell me about working with immigrant students?

\section{Administrators}

- Do immigrant students whose parents had jobs coming into Sweden receive better educational services than refugee students? Should they?

- What support has Skolverket (Swedish Ministry of Education) and/or the local community given you to better meet the needs of immigrant students?

- How have your interaction with the parents or guardians of immigrant children been?

- How do you work with immigration authorities in your community? How do they work with you and your schools?

- What do you believe would improve the educational attainment of immigrant students?

- What else would you like to tell me about working with immigrant students and parents? 
JRIT

10,1

92

Corresponding author

R.D. Nordgren can be contacted at: rnordgren@nu.edu

Students

- Were you born in Sweden? If not, where?

- What are some things about your school that you like?

- What do you like about your classmates?

- What do you like about your teachers?

- How could your school improve to meet your needs?

- Do you know if you are considered an immigrant or a refugee? Does it matter?

- What are some things about your school that you do not like?

For instructions on how to order reprints of this article, please visit our website: www.emeraldgrouppublishing.com/licensing/reprints.htm Or contact us for further details: permissions@emeraldinsight.com 